811.163.41'367.625'37

811.111'367.625'37

https://doi.org/10.18485/sj.2021.26.1.22

DEJAN M. KARAVESOVIĆ*

Оригинални научни рад

University of Kragujevac,

Примљен: 13. 10. 2020.

Faculty of Philology and Arts

Прихваћен: 12. 1. 2021.

\title{
REMARKS ON THE NATURE OF THE VERB PHASE MARKERS IN ENGLISH AND SERBIAN
}

This paper investigates different ways in which the aspectual category of the verb phase is manifested in the English and Serbian languages, aiming to establish the linguistic nature of the different modes of phasal realizations. More specifically, following Hansen and Drobnjaković's (2010) principles for identifying grammaticalized items, the analysis provides a preliminary account of main phasal properties, investigating whether the phasal realizations in the investigated languages belong in the areas of grammatical or lexical semantics. It has been observed that the principal phasal markers in both languages are phase verbs, while phasal features can also be observed at the morphological level, namely in the aspectual particles of English phrasal verbs and the prefixes with aspectual properties in Serbian derivatives. In both Serbian and English, the investigation has shown that structural and semantic properties of phase verbs point to the presence of grammatical features, while morphological markers of the phase remain within the territory of lexical semantics. The obtained results indicate that phase verbs connect the grammatical and conceptual domains of aspectual systems in both languages, setting the ground for further typological and contrastive studies on the topic.

Keywords: verb phase, phase verb, aspectual particles, the Serbian language, the English language, contrastive analysis, grammaticalization, aspect

*karavesovic@filum.kg.ac.rs 


\section{INTRODUCTION}

The linguistic category of aspect refers to "the internal temporal structure of events and activities named by various linguistic forms" (Freed 1979: 10), or as Comrie (1976: 3) concisely puts it "the internal temporal constituency of a situation". Generally speaking, two types of aspectual realizations are distinguished: aspect proper, "a fully grammaticized, obligatory, systematic category of languages, operating with general oppositions such as that of perfective and non-perfective", and Aktionsart (plural Aktionsarten), denoting "purely lexical categories, nongrammatical, optional, and unsystematic, defined in very specific terms such as inceptive or resumptive." (Binnick 1991: 170)

This characterization conforms to the distinction found in the Serbian language, in which the two aspectual features perfective : imperfective are morphologically or lexically encoded, and are fully grammaticalized (Antonić 2000: 94, Mrazović-Vukadinović 2009: 81). On the other hand, in the English language aspect is predominantly regarded as a morphosyntactic phenomenon and the property of the entire predicate, not the verb itself. It is realized analytically, either as the progressive or perfect aspect, or the combination of the two (Đorđević 1997: 436), systemically pertaining to a large number of lexical verbs. Aktionsart, however, encompasses a significantly larger number of realizations in both English and Serbian (henceforth: E and S, respectively), with various related, yet different meanings, formally represented by separate lexical units or morphological formatives (cf. Mrazović and Vukadinović 2009: 77, Binnick 1991: 139).

The category of the verb phase, typically classified under the Aktionsarten, is especially interesting since it manifests linguistic behaviour which brings it in close relation to the grammatical category of aspect, while at the same time showing properties which associate it with the lexical-semantic category of Aktionsart. In light of this interconnectedness, this paper's goal is to show that, unlike the morphological markers, the lexical markers of the verb phase in both analyzed languages can be characterized as semi-grammaticalized categories, postulating that they are intrinsically carriers of grammatical information, while semantically conveying conceptual content as well. To achieve this, I provide an overview of relevant formal and semantic properties observed in the realizations of the verb phase in E and S. These properties are subjected to a contrastive analysis at the lexical and morphological level, performed on the selected sample and aimed at specifying the nature of the investigated phenomena in terms of their grammatical status. As the paper aims to provide but a general overview of the analysed properties, accompanied by the illustrative examples, no quantitative presentation of numerical data was deemed necessary due to the lack of space and irrelevance for the format of the discussion at hand. 


\section{ANALYTICAL FRAMEWORK}

The theoretical background of the study is based on the Hansen and Drobnjaković's (2010) grammaticalization-theory oriented approach, directed at explaining "why certain linguistic forms have simultaneous lexical and grammatical functions" (p. 240), and observing that "lexical items and constructions, in specific contexts, come to be used as grammatical" (p. 239). Although grammaticalization is mostly explored through the lens of language change, this study stays within the limits of the synchronic elaboration, adhering to the premise that "the diachrony is hypothesized as manifesting itself in synchrony" (Hansen and Drobnjaković 2010: 240). To establish the traces of grammaticalization regarding the markers of the verb phase, I rely on the following criteria, laid out by Hansen and Drobnjaković (2010) and discussed in the final section of this paper:

a) PARADIGMATICIZATION - integration of the investigated items into a paradigm;

b) COMPLEMENTATION PATTERNS - reduction in the number or type of acceptable complements when compared to the other lexical items; as the current investigation involves morphological units as well, a more adequate term COMBINATORIAL PATTERNS will be used for the analysis;

c) OBLIGATORIFICATION - gradual decrease in the number of potential synonymous that can substitute the investigated item;

d) FIXATION - a strong tendency for the items within a construction to become closely interconnected, yielding a rather fixed distribution.

Hansen and Drobnjaković (2010: 244)

I employ the term Verb Phase Constructions (henceforth: VPCs) to include those verbal constructions that contain any of the phasal components as a part of their semantic composition. In this paper, the VPCs include phase verbs (henceforth: $\mathrm{PhVs})^{1}$ in $\mathrm{E}$ and $\mathrm{S}$, as the lexical markers of the verb phase, and phrasal verbs in $\mathrm{E}$ and prefixal derivatives in $\mathrm{S}$, representing morphological markers of the verb phase.

Since lexical markers of the verb phase constitute a relatively limited set, their identification was performed by referring to the consulted literature, namely Antonic (2000), Mrazović and Vukadinović (2009) and Piper et al. (2005) for S, and Freed (1979) and Egan (2008) for E. Morphological markers being more numerous, a more extensive process for the selection was required. They were preliminarily surveyed for the analysis by using Wiktionary, a comprehensive online lexical repository. ${ }^{2}$ Since entries in the Wiktionary are contributed by the general population, each identified entry required an additional attestation by using two major English monolingual dic-

\footnotetext{
${ }^{1}$ Also known as aspectual verbs of aspectualizers (Freed 1979, Newmeyer 1975)

${ }^{2}$ https://en.wiktionary.org/wiki/Category:English_phrasal_verbs (Retrieved: 11. October 2020.)
} 
tionaries, namely ldoceonline and MWOnline. ${ }^{3}$ The identification of phasal features was performed by analyzing formal and semantic properties primarily operating at the same morphosyntactic level. The criterion used for the identification of the VPCs was that each entry definition denoting a separate sense of the analyzed phrasal verb must include some sort of a phasal component, represented by the expressions begin, start, continue, end, finish or their synonymous counterparts. The identified entries were then subjected to the analysis and comparison to their closest Serbian translation equivalents, selected by employing the same identification criteria as for the English VPCs (applied by the author of this paper), using RSJ (2011) - a major monolingual dictionary of Serbian. The choice of monolingual dictionaries instead of the bilingual ones was based on the conclusion reached in the preliminary investigation that full definitions concerning verbs with phasal properties provide more relevant information for the analysis than the translation equivalents in major $\mathrm{S}-\mathrm{E} / \mathrm{E}-\mathrm{S}$ bilingual dictionaries, which offer no definitions for the entries.

\section{THE NOTION OF THE VERB PHASE}

The linguistic concept of the verb phase involves the specification of the temporal segments incorporated in the meaning of the verb with which it is associated (henceforth the matrix verb), ${ }^{4}$ in terms of "commencement, continuation or discontinuation of some sort of situation" (Egan 2008: 22; also see Plungian 1999: 313). Three main segments can be identified:

a) the starting segment - terminologically represented in the literature as inchoative, inceptive and ingressive aspectuality, marking the initiation of the event characterized by the main verb;

b) the middle segment - frequently associated with the continuative, durative or progressive $e^{5}$ aspectual features, typically conveying the meaning of ongoingness;

c) the ending segment - linked to terminative, final and egressive aspectual properties, conveying the meaning of conclusion of a situation denoted by the matrix verb; ${ }^{6}$

\footnotetext{
${ }^{3}$ https://www.ldoceonline.com (Longman Dictionary of Contemporary English Online) and https://www.merriam-webster.com (Merriam-Webster.com), respectively. All entries were retrieved on 15. October 2020.

${ }^{4}$ The term matrix verb is employed here to signify the verb from which the phase can be inferred, that is the lexical verb which combines with the phase marker. Conversely, Egan (2008) uses the same term to mark the verbs that accept non-finite complements, including PhVs.

${ }^{5}$ The last term listed in b) is usually reserved for the English grammatical aspectual category (progressiveness), but in a typological sense it can also be associated with the lexical aspect.

${ }^{6}$ See Binnick (1991: 202-207) for a more detailed elaboration of each respective term used in the classification above. In this paper, the terms listed for each subcategory will be used interchangeably as they are here taken to signal the same segment.
} 
Freed (1979: 19) extends the above differentiation into the segments denoting "the onset, beginning, continuation, duration, repetition, cessation, or completion." Drawing on the classification from the Russian authors, Dahl (1999: 31) cites numerous additional phasal meanings, such as evolutive, delimitative, perdurative, finitive, to name but a few. Stanojević and Đurić's (2019) study of resultativeness as a phasal category in French and Serbian mentions preinitial and postfinal phases as well, as does Popović (2008) in her paper on prospective aspectual meanings in Slavic languages.

Judging from these classifications alone, it is evident that the phase represents a complex category, yet it has received relatively little attention when compared to investigations of other aspectual categories. ${ }^{7}$ Within the domain of E, Newmeyer (1975) focuses on the transitivity of the aspectual verbs, arguing that they are primarily raising rather than control verbs, whose subjects must conform to the same selectional conditions as the subjects of the complement verb, rendering them intrinsically intransitive (1975: 10). Freed (1979) concentrates on the interrelatedness of syntactic and semantic properties of aspectual verbs and their complements, giving a detailed account of aspectualizers as a diagnostic tool for the identification of the well-known classification of verb types put forward by Zeno Vendler (Freed 1979: 47) - a method to be widely employed in later aspectual investigations. In a more recent study, Brinton (1985) argues that the particles of phrasal verbs mark the telic Aktionsart (i.e. heading towards a goal), which can also be associated with $\mathrm{PhVs}$. Egan's (2008) investigation of the non-finite complementation in E provides valuable distributional information about the frequency of the $\mathrm{PhVs}$ drawn from an extensive corpus, while Nagy (2016), in a similar vein, provides a semantic elaboration of aspectual verbs and their non-finite complements, introducing a pragmatic factor along with the semantic specificities of the analyzed constructions.

In the domain of Serbian linguistics, few publications dedicate specific attention to the topic of the verb phase. PhVs are frequently mentioned in grammatical handbooks, but their considerations are mostly limited to the semantic classifications of Serbian verbs (cf. Mrazović and Vukadinović 2009: 77, Piper et al. 2005: 313). Antonić (2000: 96), however, does not take the semantic criterion as the exclusive one for the characterization of the verb phase and observes that the process of the change of the grammatical aspect is linked to the concept of the phase, corroborated by the fact that $\mathrm{PhVs}$ take only imperfective verbs as complements. She asserts that "semantic marking of phase can also be realized at the morphological level. As a rule, by means of prefixal morphemes, the inherently lexical semantics of the main verb, marked at the same time as imperfective, can be modified with respect to

${ }^{7}$ In Robert Binnick's (2001) comprehensive Bibliography of Tense, Verbal Aspect, Aktionsart, and Related Areas, out of the 6600 publications, I have identified only twenty-nine (predominantly contrastive) works which consider the topic of the verb phase as the primary subject of their investigation. 
phase along with the change of verb aspect from imperfective to perfective". ${ }^{8}$ This goes counter to Mrazović and Vukadinović's (2009: 195) opinion that the concept of the verb phase is a purely lexical, semantic feature, without any grammatical properties. Here, I concur with Antonić's (2000) position and attempt to provide additional reasons for treating the $\mathrm{PhVs}$ as lexical units categorially distinct from the other verbs requiring complements, chiefly with regard to their grammatical status.

Some notable studies considering the concept of the verb phase can be found in the area of E-S contrastive studies. Glođović (2013) touches upon the notion of the phase indirectly, through the analysis of the telic character of the phrasal verbs with the particle off in $\mathrm{E}$ and corresponding prefixes in $\mathrm{S}$, showing that some phasal meanings can be morphologically realized in both languages, yet in a distributionally different manner. In his influential study of the types of the verb situation in $\mathrm{E}$ and S, Novakov (2005) extensively employs PhVs as an attested diagnostic tool in the process of determining the type of events denoted by the verbs. Reiterating the well-known fact that in S only imperfective verbs can serve as the complements of PhVs, Novakov (2005: 48) argues that the incompatibility of PhVs and perfective predicates is primarily associated with the concept of telicity, rather than the notion of completion. Additionally, Novakov (2005) provides an extensive overview of S prefixes and their E translation equivalents (2005: 68-81), which include those with phasal properties, thus serving as a valuable resource for the present study.

\section{LEXICAL MARKERS OF THE VERB PHASE}

The most frequently elaborated phase markers of VPCs are the combinations of a PHASAL LEXICAL UNIT (i.e. phase or aspectual verb) + VERB COMPLEMENT (see Antonić 2000, Dehé 2020, Egan 2008, Freed 1979, Mrazović and Vukadinović 2009, Piper et al. 2005). Due to the different criteria used for the classification of PhVs, their number differs from one publication to another. Freed (1979) investigates the properties of twelve English aspectual verbs, based on "a time-index indicating the onset, beginning, continuation, duration, repetition, cessation, or completion of [...] activities or events" (Freed 1979: 19). Egan (2008: 29) extends the number of aspectual verbs even further by listing twenty-five of them, selected by the criterion indicating whether they "normally entail the actual occurrence (or non-occurrence) of the complement situation" (2008: 27). The verbs in Table 1 are most frequently identified as phasal in the consulted literature (Antonić 2000, Egan 2008, Freed 1971, Mrazović and Vukadinović 2009, Nagy 2016):

\footnotetext{
${ }^{8}$ All citations from the literature in Serbian have been translated by the author of this paper.
} 
Table 1: English and Serbian phase verbs

\begin{tabular}{|c|c|c|c|}
\hline & Initial phase & Continuative phase & Final phase \\
\hline ENGLISH & $\begin{array}{l}\text { begin, start, commence, } \\
\text { recommence, set (about) }\end{array}$ & $\begin{array}{l}\text { continue, go on, } \\
\text { keep, remain, persist }\end{array}$ & $\begin{array}{l}\text { finish, stop, cease, } \\
\text { end up, quit, wind up }\end{array}$ \\
\hline SERBian & $\begin{array}{l}\text { početi/počinjati, } \\
\text { započeti/započinjati, } \\
\text { krenuti, stati }\end{array}$ & $\begin{array}{c}\text { nastaviti/nastavljati, } \\
\text { istrajavati }\end{array}$ & $\begin{array}{c}\text { završiti/završavati, } \\
\text { prestati/prestajati, } \\
\text { okončati/okončavati, } \\
\text { stati }^{9}\end{array}$ \\
\hline
\end{tabular}

In terms of formal realizations, verbal complements of the $\mathrm{PhVs}$ mentioned above can take the form of a finite or non-finite construction, depending on the language in which they are used. In E, the verb complements only occur as non-finites, either the infinitive or V-ing complement. On the other hand, Serbian PhVs can accept both the non-finite and finite complements, that is non-finite infinitives, or finite $D A+$ present clauses, which are invariable in terms of tense - only the temporally non-referential present is allowed: ${ }^{10}$

(1) (a) Otac je počeo/nastavio/prestao dolaziti/sedeti/grliti.

(b) Otac je počeo/nastavio/prestao da dolazi/da sedi/da grli.

(2) (a) The father began/continued/stopped coming/sitting/hugging.

(b) The father began/continued/stopped to come/to sit/to hug.

As the examples above illustrate, in each language various combinations of a $\mathrm{PhV}$ and its complement type occur, with no distributional restrictions concerning the PhVs and the same-type complement. ${ }^{11}$ Although some non-finite complements in E can express overt subjects different from their governing verbs (e.g. Father

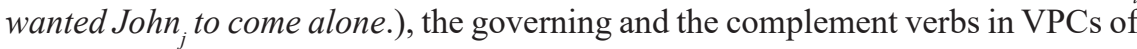
both languages cannot have overt or non-coreferential subjects. ${ }^{12}$ This indicates a strong syntactic connection between the governing $\mathrm{PhV}$ and the complement verb

${ }^{9}$ The verb stati occurs in two opposing categories, but with the homonymic status: the initial stati typically shows the unexpected beginning of an activity (cf. Piper et al. 2005: 313), as in Videvši to, najednom stade da se krsti, while the final stati denotes a cessation of an activity, as in Stade piti vino jer ga više nije bilo.

${ }^{10}$ The complements themselves can also be nominal: The students started the strike. : Studenti su počeli štrajk. As this paper's subject matter is the investigation of the verbal types of complementation, nominal complements are not included in the analysis.

${ }^{11}$ The instance of choosing one or the other type of complement (e.g. a finite vs. a non-finite one or an infinitive vs. a $V$-ing form) represents a complex phenomenon and is still a matter of numerous debates in both languages. As such, it is an issue that considerably surpasses the format of this paper, and is therefore left for further explorations on the topic.

${ }^{12}$ Freed (1979: 97) allows for some VPCs to have non-coreferential subjects, such as We kept the conversation / the war /the meetings $s_{\mathrm{j}}$ going, yet at the same time acknowledges that keep here "has a definite causative feature" (ibid 45), which I consider to be the primary trait of such expressions. 
since it restricts the potential for the complement to form an event separate from the governing $\mathrm{PhV}$.

Another distributional characteristic important for the discussion at hand is the fact that in both languages PhVs cannot be used as complements of the other PhVs (e.g. 3). This may be the case because a phasal component becomes doubled, so when the markers convey the same phasal meaning, it leads to redundancy; conversely, when two PhVs are used within a single VPC and denote two different phasal segments, this causes contradictoriness:

(3) *John started/continued/stopped starting/continuing/stopping.

*Džon je počeo/nastavio/prestao počinjati/nastavljati/prestajati.

Such behaviour resembles oppositions found in some grammatical categories, where there is a strong tendency of one category not to combine with the other category of the same sort within the same grammatical construction (e.g. present and past tense, as in *I am went, and the like).

While the grammatical aspect of the $\mathrm{PhV}$ does not affect the selection of the complement in any of the investigated languages, in $\mathrm{S}$ only imperfective verbs can serve as complements of PhVs (Antonić 2000: 95, Mrazović and Vukadinović 2009: 83, Novakov 2005: 48). Consequently, it is this feature that is used as one of the primary diagnostic tests to determine whether a Serbian verb is perfective or imperfective:

4) (a) *početi/nastaviti/prestati doći/sesti/poljubiti [ $\rightarrow$ perfective complement]

(b) početi/nastaviti/prestati dolaziti/sedati/ljubiti [ $\rightarrow$ imperfective complement $]$

Since this type of distinction between perfective and imperfective verbs is not explicitly marked in E, such restrictions are not present. Yet, certain limitations do occur. This concerns the inability of English PhVs to combine with complements marked for the perfect or progressive aspect (e.g. *start/continue/stop to have moved/ to be moving/to have been moving), an occurrence that the literature on the phase often fails to observe, but which serves as a strong indicator of the grammatical interconnectedness between the governing $\mathrm{PhV}$ and the complement.

\section{MORPHOLOGICAL MARKERS OF THE VERB PHASE}

In $\mathrm{S}$ phasal features are morphologically realized by means of prefixes, while no suffixes carrying phasal meanings have been observed. Such prefixes can be found in derivatives both with perfective and imperefective verbs (e.g. initial $z a$ in zasmejati $i_{\text {perf.. }} /$ zasmejavati $_{\text {imperf }}$ or terminative do- in dotrčat $i_{\text {perf.. }} /$ dotrčavati $i_{\text {imperf. }}$ ), standing in sharp contrast with the lexical markers of the phase, which can only be 
used with imperfective complements. Also, unlike the situation where $\mathrm{PhVs}$ cannot take another $\mathrm{PhV}$ as the complement (example 3), lexical markers of the phase can be combined with lexemes containing prefixes that manifest phasal meanings:

5) Počeo/nastavio/prestao je da zabacuje/dobacuje/prebacuje/izbacuje/ $u$ bacuje.

This is also the case when a lexeme has more than one prefix, most notably in the structures where (im)perfectivization is realized within a multiprefixal lexeme, where two or more prefixes can be combined to form a fully acceptable derivative

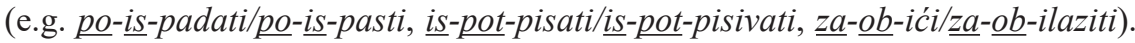
Some linguists consider this phenomenon pleonastic, yet showing no indication of redundancy (Klajn 2002: 287, Kovačević 2011: 81).

When it comes to E, morphological marking of the phase is observed in the so-called particle verbs, where in some instances particles serve as indicators of aspectual meaning within the phrasal verb construction (Glođović 2013, Walková 2017: 589). Typically, the particles are combined with matrix verbs which are not explicitly marked for aspect (see Table 2 below). ${ }^{13}$ Although formally resembling prepositions and adverbs, from which they originate, particles regularly manifest semantic bleaching, whereby some of their original prepositional/adverbial semantic features become reduced or more opaque. The most common, albeit somewhat traditional classification of phrasal verbs involves the division into three particle verb classes: compositional or spatial constructions, aspectual constructions and idiomatic constructions (see Dehé 2002: 5). The level of semantic transparency of the verbs belonging to the three separate classes varies from one verb construction to another, forming a categorial cline with pervious boundaries between the classes. These fuzzy boundaries may lead to difficulties in establishing the level of prominence of phasal meanings, but aspectual phrasal verbs, as the most relevant class for the current investigation, can be said to occupy the middle ground between the ones with the full semantic transparency (prototypical compositional phrasal verbs) and the ones manifesting the complete lack of it (prototypical idiomatic phrasal verbs) (Dehé 2002: 7).

As the literature shows, phasal features are often not the only semantic characteristics of the particles. ${ }^{14}$ Just like Serbian prefixes, particles are mostly accompanied by other semantic features, carrying 'completive' (burn down/ izgoreti), 'resultative' (figure out/prokljuviti), 'cumulative' (tear up/iscepkati), or

${ }^{13}$ Some exceptions do occur, because $\mathrm{PhVs}$ can be accompanied by aspectual particles of the same aspectual value, such as: start up (ingressive), move on (continuative), finish off (terminative). As with some Serbian prefixes, such expressions can also be viewed as pleonastic, since their semantic potential appears not to significantly contribute to the aspectual specification of the phrasal construction.

${ }^{14}$ See Klajn (2002) for a detailed exposition of the various meanings of Serbian verbal prefixes, and Dehé (2002) and Walková (2017) for the account of relevant English particles. 
'quantitative' meanings (think over/promisliti), to name a few. The particle itself can in some cases be considered to perform the role of a disambiguating element which directs the interpretation of a potentially ambiguous matrix verb toward the desired phasal reading. Consider the examples:

6) She sat in the other compartment. : Sela je u drugi kupe./Sedela je u drugom kupeu.

7) My sister drank the milk from the jug. : Moja sestra je ispila/pila mleko iz bokala.

8) The coach asked them to move. : Trener ih je zamolio da se pomere/idu.

As the examples (6)-(8) show, when contextually unresolved all the E examples fail to specify the aspectual value of the predicate. However, if modified by the use of a particle, as in sat down, drank up, move along, only the former, perfective interpretation is possible. Also, the opposite may occur as well, when the formally identical formatives represent the source of ambiguity, which further underscores the versatile character and semantic complexity of $\mathrm{E}$ and $\mathrm{S}$ formatives with phasal

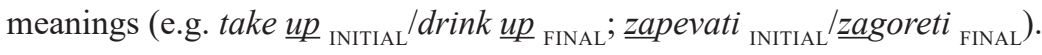

As the final illustration of demonstrating how disperse the distribution of English and Serbian morphologically marked VPCs is, I present Table 2 below. The particles were selected as representative by their frequency of occurrence in the Wiktionary ${ }^{15}$ and include up, down, off, through, on, away, about, by, in(to) and ahead. Their Serbian prefixal aspectual counterparts include: $d o-, z a-, i z-, n a-, o d-$, po-, pre-, pro-, $s(a)$-, and u-, chosen in line with Novakov's selection (2005: 6881). Clearly, a full account of all possible phasal realizations of English particles/ Serbian prefixes surpasses the intended scope and purpose of the present paper, so only a representative selection has been provided based on the potential of the phrasal verb in E or the prefixal derivative in Serbian to be paraphrased by using the combination of a PhV and the matrix verb/deverbal noun (e.g. drink up = finish drinking; pojesti $=\underline{\text { završiti jedenje). }}$

${ }^{15}$ For more information on the frequency concerning each particle and the number of associated verbs, see https://en.wiktionary.org/wiki/Category:English_phrasal_verbs 


\section{Table 2: Some examples of English phasal particles and their Serbian translation equivalents}

\begin{tabular}{|c|c|c|}
\hline & English & Serbian \\
\hline \multirow{4}{*}{$\begin{array}{l}\text { Initial } \\
\text { phase: }\end{array}$} & $\begin{array}{l}\text { lift off }=\text { start lifting (away from the } \\
\text { surface) }\end{array}$ & poleteti, $\boldsymbol{u z}$ leteti $=$ početi leteti \\
\hline & light $\boldsymbol{u p}=$ start lighting (completely) & zasvetlet $i=$ početi svetleti \\
\hline & $\begin{array}{l}\text { set about }=\text { start setting (something into } \\
\text { operation) }\end{array}$ & $\begin{array}{l}\text { nameriti se, uspostaviti }=\text { početi s } \\
\text { postavljanjem (temelja za nešto) }\end{array}$ \\
\hline & speak out $=$ start speaking (publicly) & $\begin{array}{l}\text { prozboriti }=\text { početi zboriti (nakon } \\
\text { pauze) }\end{array}$ \\
\hline \multirow{5}{*}{$\begin{array}{l}\text { Continuative } \\
\text { phase: }\end{array}$} & $\begin{array}{l}\text { move along }=\text { continue moving (to a new } \\
\text { position) }\end{array}$ & [odmicati] \\
\hline & $\begin{array}{l}\text { boss about }=\text { continue bossing } \\
\text { (persistently) }\end{array}$ & [šefovati $]$ \\
\hline & $\begin{array}{l}\text { press ahead = continue pressing (towards } \\
\text { smth.) }\end{array}$ & [izguravati] \\
\hline & $\begin{array}{l}\text { pass } \boldsymbol{b y}=\text { continue passing (past smb. or } \\
\text { smth.) }\end{array}$ & $\begin{array}{l}\text { mimoići/mimoilaziti = nastaviti } \\
\text { ići (pored nekoga ili nečega) }\end{array}$ \\
\hline & push on = continue pushing (persistently) & [izguravati] \\
\hline \multirow{9}{*}{$\begin{array}{l}\text { Final } \\
\text { phase: }\end{array}$} & $\begin{array}{l}\text { work } \boldsymbol{u p}=\text { finish working (to improve } \\
\text { smth.) }\end{array}$ & $\begin{array}{l}\text { doraditi }=\text { završiti rad (na } \\
\text { poboljšanju nečega) }\end{array}$ \\
\hline & burn down $=$ finish burning & $\begin{array}{l}\text { izgoreti, } \text { dogoreti }=\text { završiti } \\
\text { gorenje }\end{array}$ \\
\hline & $\begin{array}{l}\text { write } \boldsymbol{u p}=\text { finish writing (in a complete } \\
\text { form) }\end{array}$ & napisati $=$ završiti pisanje \\
\hline & $\begin{array}{l}\text { work off = finish working (to repay a } \\
\text { debt) }\end{array}$ & $\begin{array}{l}\text { odraditi }=\text { završiti s radom (kako } \\
\text { bi se izmirio dug) }\end{array}$ \\
\hline & $\begin{array}{l}\text { tidy up = finish tidying (the entire } \\
\text { surface) }\end{array}$ & $\begin{array}{l}\text { pospremiti }=\text { završiti spremanje } \\
\text { (za nekime) }\end{array}$ \\
\hline & $\begin{array}{l}\text { get through }=\text { finish getting (to an end of } \\
\text { difficult period) }\end{array}$ & $\begin{array}{l}\text { preboleti, prevladati }=\text { završiti } \\
\text { sa žaljenjem/okončati borbu (u } \\
\text { svoju korist) }\end{array}$ \\
\hline & $\begin{array}{l}\text { melt into }=\text { finish melting (to become one } \\
\text { with smth.) }\end{array}$ & $\begin{array}{l}\text { stopiti }=\text { završiti utapanje }(\mathrm{u} \\
\text { nešto) }\end{array}$ \\
\hline & $\begin{array}{l}\text { rust away = finish rusting (to the point of } \\
\text { destruction) }\end{array}$ & $\begin{array}{l}\text { progristi }=\text { završiti s griženjem } \\
(\text { do oštećenja) }\end{array}$ \\
\hline & $\begin{array}{l}\text { pick } \boldsymbol{u p}=\text { finish picking (fruit or } \\
\text { vegetables) }\end{array}$ & $\boldsymbol{u} b r a t i=$ završiti branje \\
\hline
\end{tabular}

${ }^{16}$ Serbian translation equivalents of English phrasal constructions that illustrate the continuative phase in Table 2 show that apart from a single prefix mimo- (see Klajn 2002: 257), which can be understood as having a continuative interpretation since it semantically does not involve any temporal endpoints, no other prefix can with a sufficient level of certainty be identified as continuative. 
As can be seen in Table 2, numerous realizations occur, and in some cases there can be more than one morphological translation equivalent in the target language (e.g. po-/uzleteti, $\boldsymbol{i}$-/dogoreti). This shows that within respective languages sometimes there is a semantic overlap among the morphological formatives containing phasal components, where with some verbs the phasal component is quite easy to discern intuitively, while with others it blends with the rest of semantic properties of the formative. Sometimes phasal meanings can be revealed if the perfective base of a prefixed verb is substituted by its imperfective counterpart, such as ispasti : ispadati. Here the perfective base pasti already carries a sense of an ending, thus obscuring the phasal meaning of the prefix yet underscoring its ablative sense. With the imperfective base, however, the phasal meaning becomes more prominent, pointing to the endings of the multiple occurrences conveyed by the imperfective matrix verb padati.

The examples also show that occasionally the decomposed predicate is not a full semantic equivalent to the construction from which it was originally generated, strongly suggesting that the prefix, if the base is transparent enough, carries more distinctive content than just a phasal meaning. This adds weight to the assumption that the phasal component serves chiefly as an additional semantical property, without any grammatical implications whatsoever.

\section{CONCLUSION}

In light of the previous elaboration, the final section of the paper will include the concluding elaboration concerning the behaviour of the phenomena investigated above set against the stated grammaticalization criteria put forward by Hansen and Drobnjaković (2010). It should, however, be borne in mind "that not all components have to be involved for a grammaticalized element to be acknowledged as such" (Hansen and Drobnjaković 2010: 245). Unless otherwise specified, the following conclusions apply for both analyzed languages.

With regard to the criterion of PARADIGMATICIZATION, the investigation has shown that the lexical expression of phase involves multiple verbs denoting each phasal segment. However, they are quite clearly instantiated, while morphological markers do not always clearly indicate to what degree the formatives contribute to the expression of phase. Except for one verb with homonymic status (stati), no other lexical markers with more than one phasal meaning were observed. This is not the case with the morphological markers, since the formatives in both languages manifest a high degree of polysemy, sometimes causing ambiguity if not contextually resolved. 
The criterion of COMBINATORIAL PATTERNING is even more revealing since lexical markers impose strict selectional restrictions throughout the entire system. In both languages they disallow combinations with other $\mathrm{PhVs}$ - they allow only imperfective verbs as complements in S, and non-progressive and non-perfect complement predicates in E. No such limits exist when it comes to the morphological markers of the phase, as they can be more freely combined with other phasal elements, lexical or morphological alike. Furthermore, lexical markers of the verb phase take temporally unspecified predicates as complements (non-finites and non-referential $D A+$ present clause), indicating that there exists a close connection between the $\mathrm{PhV}$ and the grammatically determined temporal specification of the complement predicate.

Speaking of the criterion of OBLIGATORIFICATION, it can be said that it represents the weakest factor in determining the grammatical status of both lexical and morphological markers of the phase because it is evident that the number of members in any of the presented classes of markers is considerable when compared to fully grammaticalized items, such as auxiliary verbs. However, if we take into account the fact that the same prefix can in different contexts signify different phasal meanings, the number of lexical markers appears to be significantly smaller than that of morphological markers.

When we take the final criterion, FIXATION, into consideration, it can be observed that with lexical markers of the phase, no intervening overt subject can be inserted between the $\mathrm{PhV}$ and its complement, regardless of the structural type of the complement. On the other hand, with morphological markers of the phase there exists a certain level of flexibility when it comes to their connection to the matrix verb they are attached to. More specifically, morphological carriers of phasal meanings can be doubled, or even tripled, where their additional phasal meaning is not understood as redundant. This shows that the elements of the same or opposite sort can be inserted between them and the remaining part of the base, thus demonstrating a somewhat loose connection between the morphological base and the phasal formatives. Also, the analysis has shown that a morphological phasal component can be semantically cancelled by another, typically imperfectivizing affix, while no analogous mechanism was observed when it comes to lexical markers.

Having applied the grammaticalization tests, it can be concluded that in both analyzed languages, PhVs, as the lexical markers of the verb phase, adhere to the criteria of paradigmaticization, combinatorial patterning and fixation, while the criterion of obligatorification can partly be applied. Consequently, they can be classified as grammaticalized items, but at the same time manifesting features belonging to lexical semantics, chiefly in terms of being realized through numerous synonymous lexical items conveying related, yet slightly different lexical content. In line with this, PhVs can be characterized as semi-grammaticalized structures, occupying the middle ground between fully grammaticalized auxiliaries and purely lexical verbs. On the other hand, the analysis shows that morphological markers do not conform 
to any of the criteria stated above, thus failing to be qualified as grammaticalized elements, mostly due to the prevalence their varying lexical content and lack of systemic impact on the grammatical structures which combine with them. They appear to represent a corollary semantic phenomenon, realized from the broad pool of prefixal meanings, such as spatial, directional, temporal, factive, ablative, etc, (Brinton 1985: 157; Grickat 1966/67: 186; Klajn 2002: 246-286), which in turn allows the seemingly identical aspectual markers to be combined more freely, even as pleonastic constructions. These findings may serve as a contribution to grammaticalization theory framework for both $\mathrm{E}$ and $\mathrm{S}$, but also to typological and general contrastive studies. However, being aware that the cursory character of this paper imposes certain limitations in terms of obtaining a more comprehensive perspective on the topic, it should be understood as the initial step in the unfolding of the specificities of the verb phase and related phenomena, initiating further investigations into the individual properties presented above.

\section{LITERATURE}

\section{Dictionaries}

Wiktionary: https://en.wiktionary.org

Idoceonline: https://www.ldoceonline.com/dictionary

MWOnline: https://www.merriam-webster.com

RSJ 2011: Milica Vujanić et al, Rečnik srpskoga jezika (Ed. Miroslav Nikolić), Novi Sad : Matica srpska

\section{Consulted literature}

Antonić 2000: I. Antonić, Aspekatska vrednost predikacije s faznim/modalnim glagolom na primeru rečenice s temporalnom klauzom, Južnoslovenski filolog, 56 (1-2), 93-101.

Binnick 1991: R. Binnick, Time and the Verb. Oxford: Oxford University Press

Binnick 2001: R. I. Binnick A Bibliography of Tense, Verbal Aspect, Aktionsart, and Related Areas: 6600 Works, Scarborough, Ontario: Division of Humanities - University of Toronto

Brinton 1985: L. Brinton, Verb particles in English: Aspect or Aktionsart?, Studia Linguistica, 39/2, 157-168.

Comrie 1976: B. Comrie, Aspect: An introduction to the study of verbal aspect and related problems. Cambridge: Cambridge University Press. 
Dahl 1990: Ö. Dahl. “Aspect: Basic Principles” in: Concise encyclopedia of grammatical categories, eds. E. K. Brown and Jim Miller, Amsterdam: Elsevier, 30-37.

Dehé 2002: N. Dehé, Particle verbs in English: Syntax, information structure and intonation. Amsterdam/Philadelphia: John Benjamin's.

Đorđević 1997: R. Đorđević, Gramatika engleskog jezika, Beograd: Čigoja štampa.

Egan 2008: T. Egan, Non-finite complementation: A usage-based study of infinitive and -ing clauses in English. Amsterdam and New York: Rodopi.

Freed 1979: A. Freed, The Semantics of English Aspectual Complementation, Dordrecht: Holland: D. Reidel Publishing Company.

Glođović 2013: A. Glođović, Partikule u engleskom i prefiksi u srpskom jeziku: sličnosti i razlike, Zbornik Matice srpske za filologiju i lingvistiku, LVI/1, 181-194

Grickat 1966/67: I. Grickat, Prefiksacija kao sredstvo gramatičke (čiste) perfektizacije, Južnoslovenski filolog, 27 (1-2), 185-224.

Hansen and Drobnjaković 2010: B. Hansen and A. Drobnjaković. Grammaticalization theory as a basis for the panchronic study of the Serbian language: setting the agenda. In: (eds. J. Grković-Mejdžor and M. Radovanović) The theory of diachronic linguistics and investigations into the Serbian language, Belgrade: Serbian Academy of Sciences and Arts, 239-263.

Klajn 2002: I. Klajn, Tvorba reči u savremenom srpskom jeziku-Prvi deo: Slaganje i prefiksacija. Beograd - Novi Sad: Zavod za udžbenike i nastavna sredstva, Institut za srpski jezik SANU, Matica srpska.

Kovačević 2011: M. Kovačević, Pleonastička upotreba prefiksa u srpskome jeziku, in: M. Kovačević, Gramatička pitanja srpskoga jezika, Beograd, Jasen, 81-101.

Mrazović and Vukadinović 2009: P. Mrazović i Z. Vukadinović, Gramatika srpskog jezika za strance, Sremski Karlovci - Novi Sad: Izdavačka knjižarnica Zorana Stojanovića.

Nagy 2016: T. Nagy, On aspectualizers in English. A corpus-based Approach, Scientia Publishing House: Cluj-Napoca.

Newmeyer 1975: F. J. Newmeyer, English Aspectual Verbs. Berlin, Boston: De Gruyter Mouton.

Novakov 2005: P. Novakov, Glagolski vid i tip glagolske situacije u engleskom $i$ srpskom jeziku, Novi Sad: Futura publikacije. 
Piper et al. 2005: P. Piper et al, Sintaksa savremenoga srpskog jezika. Prosta rečenica, Beograd - Novi Sad: Institut za srpski jezik SANU, Beogradska knjiga, Matica srpska.

Plungian 1999: V. A. Plungian, A typology of phasal meanings, in W. Abraham and L. Kulikov (eds.), Tense-Aspect, Transitivity and Causativity: Essays in honour of Vladimir Nedjalkov, Amsterdam: John Benjamins Publishing Co., 311-321.

Popović 2008: Lj. Popović, Izražavanje aspektualnog značenja prospektivnosti u slovenskim jezicima, Zbornik Matice srpske za slavistiku, 73, Novi Sad: Matica srpska, 297-314.

Stanojević and Đurić 2019: V. J. Stanojević, Lj. Z. Đurić, Aspekat kao fazna kategorija i rezultativnost u francuskom i srpskom jeziku, Srpski jezik, 24, 221-233.

Tommola 1983: H. Tommola, On the aspectual significance of'phase meanings, in C. de Groot and H. Tommola (eds.), Aspect Bound: A voyage into the realm of Germanic, Slavonic and Finno-Ugrian aspectology, Dordrecht : Foris Publications, 111-132.

Walková 2017: M. Walková. Particle verbs in English: Telicity or scalarity?, Linguistics, 55(3), 589-616.

\section{O PRIRODI MARKERA GLAGOLSKE FAZE U ENGLESKOM I SRPSKOM}

\section{Резиме}

Следећи принципе идентификације граматикализованих структура Хансена и Дробњаковићеве (2010), рад настоји да пружи прелиминарни преглед обележја везаних за глаголску фазу у енглеском и српском језику како би се утврдило да ли се појединачне фазне реализације могу сврстати у подручје граматичке или лексичке семантике. Примећено је да главни маркери категорије фазе у оба језика јесу фазни глаголи, док се обележја фазе могу уочити и на морфолошком нивоу, пре свега у аспекатским партикулама енглеских фазних глагола, као и префиксима са аспекатским својствима код српских изведеница. Истраживање је показало да у оба језика структурна и семантичка својства фазних глагола указују на њихову донекле граматикализовану природу, док морфолошки експоненти фазе остају у потпуности у домену лексичке семантике. Добијени резултати указују на то да фазни глаголи у оба језика повезују граматички и концептуални домен аспекат- 
ских система оба језика, постављајући основу за даља типолошка и контрастивна истраживања на ову тему.

Кључне речи: глаголска фаза, фазни глагол, аспекатске партикуле, српски језик, енглески језик, контрастивна анализа, граматикализација, аспект.

Дејан М. Каравесовић 